\title{
EDITORIAL
}

\section{GEORGE MASCARENHAS}

IVANI SANTANA

\section{ESPERANÇA EQUILIBRISTA: ARTE COMO REDE DE PROTEÇÃO}

$\mathrm{O}$ ano de 2020 tem se mostrado como um grande desafio para a humanidade, com as demandas e consequências da pandemia de COVID-19.

Somente no Brasil, dados do Ministério da Saúde indicam que até dezembro deste ano contabilizaram-se 193.875 mortes e mais de sete milhões e quinhentos mil casos de contaminação. Apesar disso, o site oficial do Ministério destaca o número de pessoas recuperadas, privilegiando uma narrativa que desconsidera a gravidade do número de mortos e infectados. 
Para o setor cultural e, particularmente, para as artes cênicas, os impactos são devastadores também do ponto de vista econômico. Um estudo nacional realizado pela Fundação Getúlio Vargas, com a Secretaria de Cultura e Economia Criativa do Estado de São Paulo e o SEBRAE, no mês de julho, indica uma queda superior a 31\% do PIB da cultura em 2020, com quase $90 \%$ de registro de queda no faturamento, $42 \%$ de projetos cancelados e impossibilidade de realização de atividades na quarentena para mais de $63 \%$ dos casos.

A lei de auxílio emergencial para o setor cultural, chamada Lei Aldir Blanc, aprovada em junho pelo Congresso Nacional, após grande pressão do setor, foi regulamentada apenas em agosto pelo Governo Federal e, em muitas regiões do país, os benefícios só começaram a ser pagos a partir de novembro, cerca de oito meses depois do reconhecimento oficial da pandemia no Brasil.

A despeito das grandes dificuldades para sobrevivência, atores, diretores, dramaturgos, grupos e companhias se empenharam em seguir caminhos para o enfrentamento da crise. Nesse período, pudemos ter acesso a experimentos de artistas de renome nacional e internacional, a novas criações dramatúrgicas ou exibição de espetáculos já realizados e diálogos profícuos entre as artes cênicas e a linguagem audiovisual, em canais de acesso gratuito. Ao longo dos últimos nove meses, vimos surgir propostas artísticas, discussões acaloradas sobre "novos" formatos e adjetivações para o teatro - teatro digital, webteatro, teatro on-line, lives de teatro, teatro virtual - não por uma opção de investigação artística, o que já acontece há algumas décadas para vários grupos, mas por ter se tornado a única possibilidade de expressão, criação e contato com o público. Diversos artistas, alguns dos quais antes declaradamente avessos às interfaces tecnológicas, se viram compelidos a elaborar e participar de criações artísticas com base nessa mediação.

Curiosamente, o investimento dos artistas em criações que revelam as dificuldades e perspectivas da pandemia em 2020 ecoam atitudes artísticas da pandemia de Gripe Espanhola de 1918. No artigo The Spanish 1918 Flu and the COVID-19 Disease: The Art of Remembering and Foreshadowing Pandemics, Joseph Goldstein (2020) aponta grandes semelhanças com a covid-19, como na relação de transmissão pessoa-a-pessoa e alta letalidade e afirma que artistas 
da época, como Edvard Munch e John Singer Sargent nos contaram, através de suas obras de arte, “em tempo real, como era ser afetado pela gripe espanhola”.

Em tempo real, com transmissões diretas ao vivo, artistas da cena no mundo inteiro, em 2020, vêm mostrando as dores do confinamento, os impactos sobre a vida das comunidades, as incompetências políticas, a excessiva politização sobre decisões acerca da vida e da morte, os efeitos sobre a própria arte. Na total ausência de espectadores presenciais ou com o número reduzido pelos protocolos de segurança para a saúde pública, as telas de smartphones, tablets, TVs vêm sendo preenchidas por experiências marcadamente teatrais. Assim, por exemplo, em Um concerto para um guarda roupa, performance em vídeo realizada em Salvador-Ba, os corpos artísticos do Teatro Castro Alves - o Balé do Teatro Castro Alves e a Orquestra Sinfônica da Bahia - se apresentam para uma plateia formada pelos figurinos do Centro Técnico, que ocupavam as poltronas do teatro fechado. Em Galileu e eu, transmitida no canal do projeto SESC em casa, Denise Fraga brinca com seu processo de criação para a peça de Brecht, criticando a onda de obscurantismo anticientífico que invadiu a esfera política do país. E recentemente, o National Theatre de Londres ofereceu transmissões de Death of England - Delroy, sobre identidade, classe e raça no Reino Unido, em clara articulação com o movimento Black Lives Matter. Na plateia do teatro, viam-se espectadores com máscaras em assentos alternados.

Compreendemos, em meio a tudo isso, que o mergulho na experiência artística se configura, assim, como uma possibilidade de saída e resistência, como rede de proteção, em meio a tantas impossibilidades e como declaração da necessidade de enfrentamento, empenho, investimento e fomento na criação, produção e pesquisa artística e cultural. Com a segunda parte do dossiê O Circo - ontem e hoje, no perfil Persona com Lia Rodrigues e nas reflexões sobre o ensino e a produção artística da Repertório Livre, fechamos o ano com o desejo de que essas leituras abram novos caminhos e possibilidades, novas transgressões, outras palavras, uma esperança equilibrista. 